\title{
Delineating small karst watersheds based on digital elevation model and eco-hydrogeological principles
}

\author{
Guang Jie Luo ${ }^{1,2,3}$, Shi Jie Wang ${ }^{1}$, Xiao Yong Bai ${ }^{1}$, Xiu Ming Liu ${ }^{1}$, and An Yun Cheng ${ }^{4}$ \\ ${ }^{1}$ State Key Laboratory of Environmental Geochemistry, Institute of Geochemistry, Chinese Academy of Sciences, \\ Guiyang 550081, China \\ ${ }^{2}$ University of Chinese Academy of Sciences, Beijing 100049, China \\ ${ }^{3}$ Institute of Agricultural Ecology and Rural development, Guizhou Normal College, Guiyang 550018, China \\ ${ }^{4}$ Puding Karst Ecosystem Observation and Research Station, Chinese Academy of Sciences, Anshun 561000, China \\ Correspondence to: Shi Jie Wang (wangshijie@vip.gyig.ac.cn)
}

Received: 27 January 2016 - Published in Solid Earth Discuss.: 29 January 2016

Revised: 6 March 2016 - Accepted: 15 March 2016 - Published: 29 March 2016

\begin{abstract}
Dominated by specific eco-hydrogeological backgrounds, a small watershed delineated by using the traditional method is always inauthentic in karst regions because it cannot accurately reflect the eco-hydrological process of the dual structure of the surface and subsurface. This study proposes a new method for the delineation of small watersheds based on digital elevation models (DEMs) and ecohydrogeological principles in karst regions. This method is applied to one section of the tributary area (Sancha River) of the Yangtze River in China. By comparing the quantity, shape, superimposition, and characteristics of the internal hydrological process of a small watershed extracted by using the digital elevation model with that extracted by using the proposed method of this study, we conclude that the small karst watersheds extracted by the new method accurately reflect the hydrological process of the river basin. Furthermore, we propose that the minimum unit of the river basin in karst regions should be the watershed, whose exit is the corrosion and corrasion baselevel and a further division of watershed may cause a significant inconsistency with the true eco-hydrological process.
\end{abstract}

\section{Introduction}

Karst is the term used to describe a special type of landscape containing caves and extensive underground water systems that is developed particularly on soluble rocks, such as limestone, marble, and gypsum (Ford and Williams, 2007). By the action of lithology and tectonics, soluble carbonate rocks form a dual structure by corrosion and corrasion in the surface and subsurface. This structure with severe heterogeneity causes complex hydraulic conditions and spatiotemporal variability of parameters (Meng et al., 2015). Rain falls into shafts and sinks, thus causing the subsurface to crack rapidly, particularly in several karst mountain areas, the water infiltration coefficient is up to $80 \%$ (Liu and Li, 2007; Meng and Wang, 2010) and the soil loss is also strong (Febles et al., 2014). Thus, karst eco-hydrological processes are characterized as the dual structure of the surface and subsurface (Yang, 1982). The amounts of surface runoff and soil loss on karst slopes are small compared with non-karst areas because of the dual hydrological structure of karst regions, including ground and underground drainage systems. Most rainfall water is transported underground through limestone fissures and fractures, whereas only a small proportion of rainfall water is transported in the form of surface runoff (Peng and Wang, 2012). Moreover, karst also provides diverse subterranean habitats, including epikarst, cave streams, drip pools, springs, and interstices (Bonacci et al., 2009). In karst regions a large number of studies have focused on hydrology, soil erosion, water resources, and ecosystems based on the watershed unit (Rimmer and Salingar, 2006; Navas et al., 2013; McCormack et al., 2014). However, many studies do not assess the accuracy of the scope of the watershed, or several only assess the catchment scope for a single spring in the watershed (key papers are summarized in Table 1 in relation). In summary, a small watershed is the basic unit between ecosystem manage- 
Table 1. Summary of relevant field studies based on watershed scale in karst areas. Not all papers illustrated data and method to map the scope of the studied watershed and these are denoted with "N/A" representing "not applicable" in the relevant part of the "Data/method to map the scope of the watershed" column. The "Key results" column, the accuracy of the scope of the watershed is identified. Many studies do not make an assessment, and N/A directly follows the code in such cases.

\begin{tabular}{|c|c|c|c|c|}
\hline Study & Field & Location/watershed/study size & $\begin{array}{l}\text { Data/method to map the scope } \\
\text { of the watershed }\end{array}$ & Key results \\
\hline 1 - Majone et al. (2004) & Karst runoff & $\begin{array}{l}\text { Northeastern Italy } / \text { Centonia and Prese } \\
\text { Val } / 20.6 \text { and } 1.96 \mathrm{~km}^{2}\end{array}$ & N/A / N/A & N/A \\
\hline 2 - Rimmer and Salingar (2006) & $\begin{array}{l}\text { Precipitation- } \\
\text { streamflow } \\
\text { model }\end{array}$ & $\begin{array}{l}\text { Hermon mountain, Jordan River/Dan, } \\
\text { Snir and Hermon } / 252,118,106 \mathrm{~km}^{2}\end{array}$ & digital terrain model (DTM)/N/A & N/A \\
\hline 3 - Bailly-Comte et al. (2009) & Hydrodynamics & $\begin{array}{l}\text { Near Montpellier, Southern } \\
\text { France/Coulazou River } / 61 \mathrm{~km}^{2}\end{array}$ & N/A / N/A & N/A \\
\hline 4 - Mayaud et al. (2014) & $\begin{array}{l}\text { Groundwater } \\
\text { hydraulics }\end{array}$ & Styria, Austria/Lurbach $/ 23 \mathrm{~km}^{2}$ & geological map/investigation & $\begin{array}{l}\text { Surface Lurbach stream: } 15 \mathrm{~km}^{2} \text {, } \\
\text { subsurface karstified unit: } 8 \mathrm{~km}^{2}\end{array}$ \\
\hline 5 - Malard et al. (2015) & $\begin{array}{l}\text { Groundwater } \\
\text { hydraulics }\end{array}$ & $\begin{array}{l}\text { Northeastern Switzerland/Beuchire- } \\
\text { Creugenat (BC) and Bonnefontaine- } \\
\text { Voyeboeuf (BV)/58 and } 19 \mathrm{~km}^{2}\end{array}$ & geological map/investigation & $\begin{array}{l}\text { BC: Autogenic parts } 50.5 \mathrm{~km}^{2} \text { and } \\
\text { Allogenic parts } 6.5 \mathrm{~km}^{2} \text {, respectively } \\
\text { BV: } 16.5 \text { and } 2.5 \mathrm{~km}^{2}\end{array}$ \\
\hline 6 - Yue et al. (2015) & $\begin{array}{l}\text { Nitrate } \\
\text { sources and } \\
\text { transformation } \\
\text { processes }\end{array}$ & Southwestern China/Houzhai/ $/ 81 \mathrm{~km}^{2}$ & N/A / N/A & N/A \\
\hline 7 - Wicks (1997) & $\begin{array}{l}\text { Groundwater } \\
\text { hydraulics }\end{array}$ & $\begin{array}{l}\text { Central Missouri, } \\
\text { USA/Bonne Femme } / 31.6 \mathrm{~km}^{2}\end{array}$ & $\begin{array}{l}\text { N/A/surface-water drainage patterns, } \\
\text { topography, and dye tracing }\end{array}$ & $\begin{array}{l}\text { Surface stream: } 21.3 \mathrm{~km}^{2} \text {, subsurface } \\
\text { stream: } 10.3 \mathrm{~km}^{2}\end{array}$ \\
\hline 8 - Ravbar and Goldscheider (2009) & $\begin{array}{l}\text { Groundwater } \\
\text { vulnerability } \\
\text { mapping }\end{array}$ & $\begin{array}{l}\text { Southwestern } \\
\text { nia/Podstenjšek } / 9.1 \text { km² }\end{array}$ & N/A / N/A & N/A \\
\hline 9 - Navas et al. (2013) & $\begin{array}{l}\text { soil } \\
\text { redistribution }\end{array}$ & $\begin{array}{l}\text { Spanish Pyrenees/Estanque de Arriba } \\
\text { Lake } / 0.8 \mathrm{~km}^{2}\end{array}$ & Digital elevation models (DEMs)/N/A & N/A \\
\hline 10 - McCormack et al. (2014) & $\begin{array}{l}\text { groundwater } \\
\text { discharge and } \\
\text { nutrient }\end{array}$ & $\begin{array}{l}\text { Western Ireland } / \text { Gort } \\
\text { Lowlands } / 483 \mathrm{~km}^{2}\end{array}$ & N/A / N/A & N/A \\
\hline
\end{tabular}

ment and basic science research in karst areas (Xiong et al., 2014; Doglioni et al, 2012), and the method of delineating karst watersheds has been illustrated in geographical landscape scale (e.g. more than $100-10000 \mathrm{~km}^{2}$ ) by considering the karst dual structure in the surface and subsurface.

Watersheds, which have boundaries shaped by geomorphic and physical processes rather than political borders (Hollenhorst et al., 2007), have become more accepted as the basic unit for water resource management and ecological protection (NRC, 1999). The digital elevation models (DEMs) provide a solid technical foundation for the development of a digital hydrological model that can be used for watershed extraction and topographic analysis (Mantelli et al, 2011; Li and Hao, 2003). Basin delineation is generally based on digital morphology and consists of two major steps: removal of all pits within the model by using an original morphological mapping, delineation of the topographic basins by using morphological thinning with specific structuring elements (Soille and Ansoult, 1990). The DEMs are one of the many products available for public use that provide information regarding new data sets for drainage extraction and watershed delineation (Hancock et al., 2006). Therefore, the extraction of the topographic information of watersheds, such as ridge lines, stream networks, and watershed area, from DEMs has been utilized ed since the early 1970s (Peucker and Douglas, 1975; Gallant and Hutchinson, 2009). In previous studies, the flow accumulation value (the number of grid cells that drain into a particular cell) was calculated to establish drainage networks (Marks et al., 1984; O'Callaghan and Mark, 1984). The procedure of partitioning watersheds within the DEMs consists of three phases, namely, delineation of a channel network, delineation of a drainage divide network, and labelling of the basins by assigning each pour point a unique positive integer and drainage direction (Band, 1986). Thereafter, the interior of each basin is labelled according to its pour point identifier (Benosky and Merry, 1995). In recent years, automated watershed extraction based on DEMs has been extensively used, particularly the combination of DEMs with advances in geographic information system (GIS) techniques, as a tool for watershed extraction (García and Camarasa, 1999; Ahamed et al., 2002; Vogt et al., 2003; Hollenhorst et al., 2007; Qiu and Zheng, 2012).

China has approximately $3.44 \times 10^{6} \mathrm{~km}^{2}$ of karst areas, which is approximately $36 \%$ of its total land area and $15.6 \%$ of all $22 \times 10^{6} \mathrm{~km}^{2}$ karst areas in the world (Jiang et al., 2014a). The continuously distributed karst region, which is about $540000 \mathrm{~km}^{2}$, including eight provinces in southwest China (Xu et al., 2015), is one of the most extensive and welldeveloped karst landscapes of the world (Wang et al., 2004). Rocky desertification, which is used to characterize the pro- 
Table 2. Quantity of all types of strata outcropped in the study area.

\begin{tabular}{llr}
\hline \multicolumn{2}{c}{ Geological time } & $\begin{array}{r}\text { Percentage of } \\
\text { strata outcropped } \\
(\%)\end{array}$ \\
\hline Cenozoic & Quaternary & 3.4 \\
& Paleogene & 1.06 \\
Mesozoic & Triassic & 64.04 \\
Upper Paleozoic & Dyas & 26.92 \\
& Carboniferous & 5.91 \\
Lower Paleozoic & Devonian & 0.5 \\
& Ordovician & 0.03 \\
& Cambrian & 2.14 \\
\hline
\end{tabular}

cesses that transform a karst area covered by vegetation and soil into a rocky landscape almost devoid of soil and vegetation (Yan, 1997), has become one of the most important eco-environmental problems in China (Bai et al., 2013; Yan and Cai, 2015). Therefore, a comprehensive harness outline for desertification in karst regions (2006-2015) in southwest China projects approved by the State Council of the People's Republic of China and funded by the Chinese government at different levels has resulted in significant progress in ecological restoration in recent decades (Xiao et al., 2014). Small watershed is a basic unit to implement these projects. We cannot always rely directly on automatically extracted watersheds, particularly in regions with internal drainage (e.g. karst regions) or in plateau areas, where filling depressions can produce large uncertainties in the extracted networks and watershed boundaries (Khan et al., 2014). Automated watershed extraction based on the DEMs of the surface morphological characteristic of the Earth seems necessary to improve the methods used. Automatically delineated surface small watersheds do not always show close agreement with subsurface small watersheds because the subsurface hydrological process is not considered, thus leading to the distortion in the basin boundary and hydrological and ecological processes. This phenomenon further restricts scientific water resource management and ecological restoration projects. Thus, the accurate extraction of karst watersheds $(\mathrm{KW})$ is important.

This study aims to characterize and compare the proposed extraction method of small karst watersheds, combining the landscape characteristics and eco-hydrogeological principles with the traditional watershed extraction method that topographic small watersheds are delineated automatically (ATW). We select a typical karst area to extract the KW. The study site is a section of Sancha River upstream of Wujiang River, a branch of the Yangtze River in China. The results can be used to accurately assess eco-hydrological processes and efficiently manage karst watersheds.

\section{Methods}

\subsection{Study site}

Our study area on the Qianzhong Plateau $\left(A=2193.14 \mathrm{~km}^{2}\right)$ is the part of the Sancha River upstream of the Wujiang River, a branch of the Yangtze River in China (Fig. 1). The elevations of the study area vary between 1042 and $1846 \mathrm{~m}$ a.s.l. The climate type is north subtropical monsoon, with a high mountain influence. In recent decades, the mean annual rainfall amount is $1400 \mathrm{~mm}$ and peaks in the summer season during storm events and the annual average temperature is $15.6^{\circ} \mathrm{C}$ (For data between 1961 and 2006). Strata from the Cambrian of the Lower Paleozoic Erathem to the Quaternary of the Cenozoic Erathem, except Silurian, Jurassic, and Cretaceous, all exhibit exposures. Among these exposures, the carbonate rocks of Permian and Triassic are most widely distributed, accounting for greater than $90 \%$ of the study area (Table 2). Karst develops intensively. Thus, karst landforms, such as dolines, karren zones, and dry valley, are visible on the plateau, thus indicating that karstification is relatively high in the study zone with 23 underground rivers. The Yelanghu Reservoir, constructed in the study area in 1994, has become one of the main freshwater sources in Anshun, which supply drinking water to the city (Zhang et al., 2011). The Sancha River is the largest river in the study area and is considered to be the corrasion baselevel of the study area.

\subsection{Materials}

Data used in this study include 1: 50000 digital line graphic (DLG) data provided by the State Key Laboratory of Environmental Geochemistry (transformed into DEMs, with a resolution of $30 \mathrm{~m}$, by using ArcGIS), geological data, hydrogeological data obtained through hydrogeological mapping, hydrogeological drilling, water quality tracing experiment based on geophysical prospecting, and high-resolution remote sensing image data (resolution of $<2 \mathrm{~m}$ ). In 2012, precipitation in the study area is the data provided by the online observation of ecosystems and by research stations in China (Chinese Ecosystem Research Network (CERN), Puding). The aforementioned data sources are used in ArcGIS to establish a coordinate system that can be used to conduct spatial analysis. After the indoor extraction of $\mathrm{KW}$ based on the method previously presented, we conducted considerable field work to verify the boundary of small watershed on site.

\section{Method}

In this study, the delineation of karst watersheds (KW) is completed by the following five steps: (i) auto-delineating topographic watersheds (ATW) is delineated by using the hydrological tools in ArcGIS 10 (ESRI 2010), (ii) regional corrosion and corrasion baselevel and exit of watershed are determined, (iii) the trunk stream of the dual structure of the 


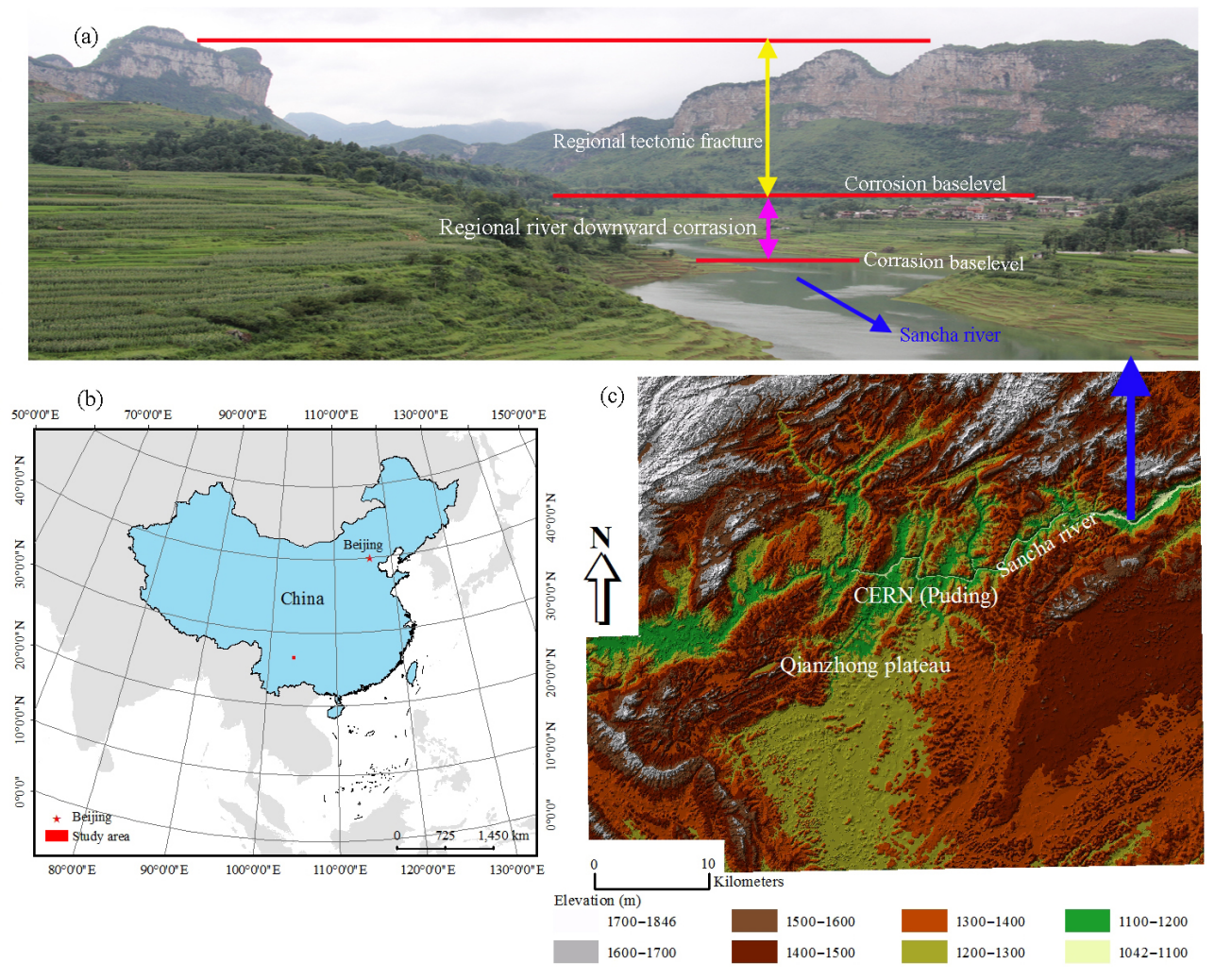

Figure 1. Location and topography of the study area. (a) Is the general view of Sancha river, (b) is the location of the study area and (c) is the elevation map of the study area.

surface and underground is determined, (iv) the flow direction in the permeable stratum of karst carbonate in the region is determined, (v) the divide of watershed is corrected and $\mathrm{KW}$ extraction is completed.

\subsection{Extraction of auto-delineating topographic watersheds (ATW)}

By adopting the traditional method of automatic extraction, this step is completed by using the hydrological tools available in ArcGIS (Martz and Garbrecht, 1999). TIN is firstly established by using the digital line graphic (DLG) data and is converted to DEMs data, but DEMs data can also be obtained from existing data (such as ASTER DEMs and SRTM DEMs). Thereafter, flow distribution is conducted by using the commonly adopted D8 algorithm (Mark, 1984; O'Callaghan and Mark, 1984). However, in actual DEMs products, grids around the karst regions are higher than the depressions because of false data or the existence of "pits" or "sinks" in actual terrain. This phenomenon results in the retention of runoffs in depressions. Consequently, the extracted river network is discontinued and deviation errors occur in the flow direction and river network (Nikolakopoulos et al., 2006; Jiang et al., 2014b; Tarboton et al., 1991). Therefore, the pretreatment of DEMs data is necessary to fill the depressions in the data. After this process, the elevation value of the grid of the depression is equal to the elevation value of the surrounding lowest point. By modifying the elevation value specified previously, the elevation values of all grids in the DEMs are larger than or equal to that of the lowest outlet. In this manner, a DEM "with hydrological meaning" is generated and the continuity of the natural water system of the watershed extracted from DEMs data can be ensured ( $\mathrm{Li}$ et al., 2003).

After filling the depressions, the elevation of each DEMs grid can be compared with its adjacent grids in 8 directions. The direction with the steepest slope is the direction of the runoff in this grid (Kiss, 2004; Jenson and Domingue, 1988). In ArcGIS, grids obtained after the calculation of the flow direction are marked as 1, 2, 4, 8, 16, 32, 64, and 128 to record the different flow directions of grids. On the basis of the determined flow directions of grids, the area of the upstream catchment of this grid is determined by calculating the number of grids whose upstream catchment flows directly or indirectly to the designated grid (Jensen, 1991). After generating an output raster of flow accumulation, the threshold of the grid where flows accumulated is selected as the area threshold of the upstream feeding area on the basis of the characteristics of climate in a certain region. The grid whose threshold is equal to the area threshold is adopted as the initial point of the watercourse. Grids with thresholds greater than the area 
threshold constitute the watercourse (Qiu et al, 2012). Furthermore, watershed and sub-watershed outlets can be defined by using the accumulated area raster. Thereafter, the watershed can be delineated and the watershed boundary can be converted to a vector polygon by using GIS tools (Khan et al., 2014).

\subsection{Determination of the regional corrosion and corrasion baselevel and exit of watershed}

Influenced by regional tectonic activities, the datum plane significantly affects the hydrological and geomorphic processes within a certain region (Fitzpatrick, 1998). The corrasion baselevel is usually at the level of the adjacent large river instead of the sea level in most parts of a karst region. As such, the erosion baselevel is associated with the sea level through the trunk stream (Li and Cui, 2004). The regional tectonic uplift and strong downcutting of the river cause the formation of relatively independent water-bearing blocks locally. In most cases, independent recharge, runoff, and discharge areas exist in each block, which leads to the exposure of subterranean rivers or karst springs around the discharge datum plane in karst regions (Yang, 1982). As a result, the place where subterranean rivers or karst springs is exposed can be turned into a perpetual open channel because the corrosion baselevel of this area in karst regions can be used to determine the exit of watersheds (shown in Fig. 2a). The main watercourse of a large river in the region is considered to be the regional corrasion baselevel line (shown in Fig. 2b). In this manner, the line linking corrosion baselevel and corrasion baselevel is the regional corrosion and corrasion baselevel line (shown in Fig. 2c). In watershed management, the intersection of the corrosion and corrasion baselevel line and the main watercourse of the large river is considered to be the exit of the KW (shown in Fig. 2d).

\subsection{Determination of the trunk stream of the dual structure of the surface and underground in karst watersheds $(\mathrm{KW})$}

As stated in Sect. 3.2, the watercourse of the large river, which can be extracted automatically based on the DEMs, is the trunk stream of the watershed in the downstream area of the regional corrosion and corrasion baselevel in karst regions. By contrast, the main watercourse is often characterized by the alteration of open channels and subterranean streams in the upstream area of the corrosion and corrasion baselevel because of the effects of the lithologic characteristics and structure of stratum, fault, and folding. In the area of subterranean streams, the error rate of the automatic extraction of trunk stream based on the DEMs is high. Thus, the manual correction of the trunk stream of ATW can be conducted from the upstream watercourse to the exit of $\mathrm{KW}$ by using terrain data, high-resolution images, and hydrogeological data. The correction process is shown on the left of Fig. 3.

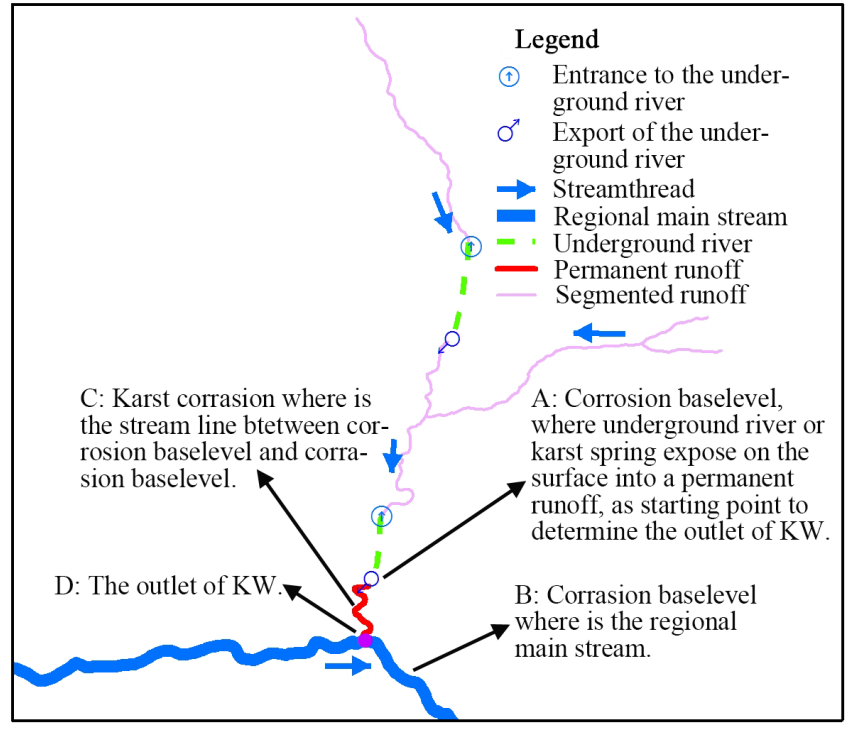

Figure 2. Schematic used to determine the outlet of karst watersheds $(\mathrm{KW})$.

In the upstream area of (1) ATW featuring clastic rocks, the trunk stream is the surface runoff that enters the carbonatite area at site a. The trunk stream turns into a subterranean river and flows to the (2) area. At site b, the subterranean river encounters the water-resisting layer of clastic rocks and flows to (3) the ATW area through sunken pipes. Finally, the subterranean river flows out of the surface at b in the (4) ATW area. The trunk stream reaches the exit of the $\mathrm{KW}$ and enters the watercourse of the regional large river (corrasion baselevel). According to the high-resolution images, no overland runoffs exist in the automatically extracted areas where the trunk stream flows through in the eastward direction of a in the (1) ATW, the eastward direction of b in the (2) ATW, and the southward direction of $\mathrm{c}$ in the (3) ATW. The hydrological processes of these areas are dominantly underground processes. Thus, manual correction is necessary on the topographic trunk stream extracted automatically in these areas to obtain the trunk stream on the basis of the dual structure of the surface and underground in the KW.

\subsection{Determination of the flow direction in the permeable strata of karst carbonatite in the regions where trunk stream flows through}

After the determination of the trunk stream of the surface and underground in $\mathrm{KW}$, determining the flow direction of each hydrogeological unit in the area it flows through becomes an important step for the extraction of KW. In non-karstic terrains, groundwater divides are assumed to directly underlie the surface topographic divides as determined from contour maps and aerial photographs (Ford and Williams, 2007). However, in karst areas, groundwater flow is significantly independent of topography but is often guided by geological 


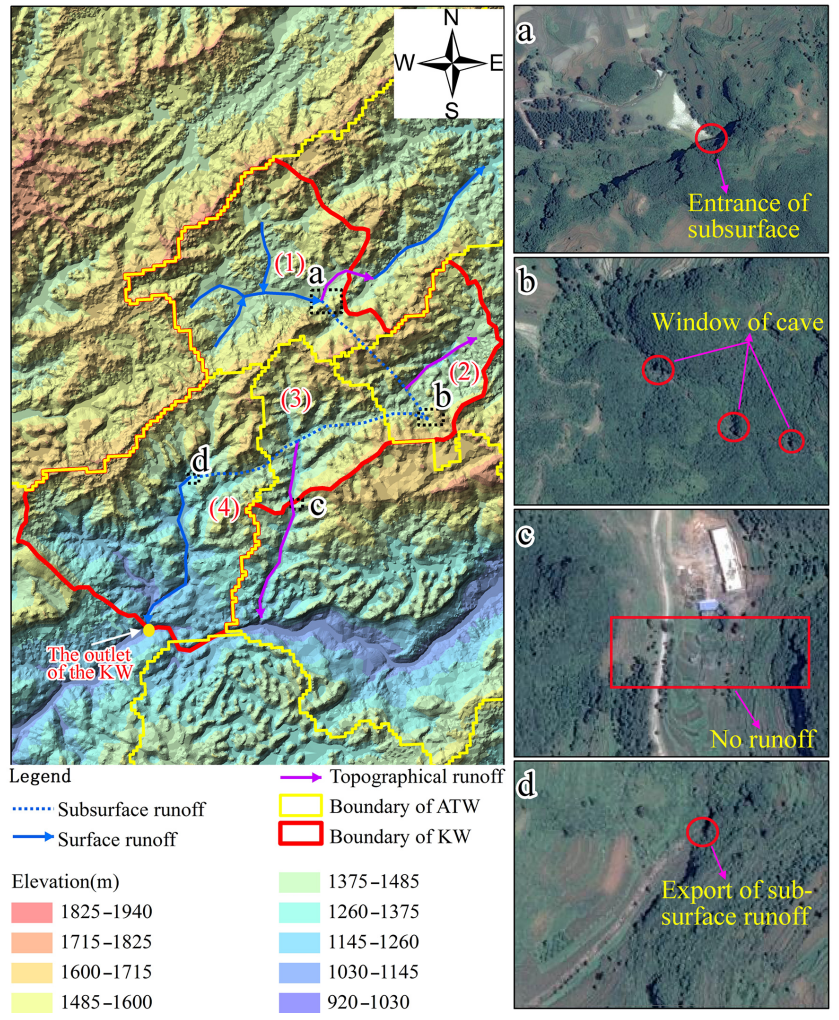

Figure 3. Process used to determine the trunk stream of the dual structure of the surface and subsurface in karst watersheds (KW). ATW represents "auto-delineating topographic watersheds".

formations and structures (Nico and David, 2007). Therefore, in areas without carbonatite, the flow direction is determined on the basis of the surface terrain. By contrast, in carbonatite areas, the flow direction is determined by considering the lithological characteristics and the combination of strata, fault, and structure and by conducting geophysical survey, tracing experiment, and model simulation (Rugel et al., 2016). On this basis, the distribution of watershed in the area with permeable strata in karst carbonatite is determined.

\subsection{Correction of the divide of auto-delineating topographic watersheds (ATW)}

After completing the steps presented in Sect. 3.4, the watershed distribution of all karst hydrogeological units is almost completely determined. Corrections on several divides extracted automatically are imperative to enable the boundary of the dividing area to reflect the karst hydrological process more accurately. Two conditions must be considered in the process of correction. (1) The divide runs through areas featuring clastic rocks (not carbonatite) with water-resisting layers or slopes where the terrain changes significantly. Considering the fact that the hydrological process of these areas is mainly characterized by surface runoffs, the watershed boundary of $\mathrm{KW}$ is considered to be the watershed boundary

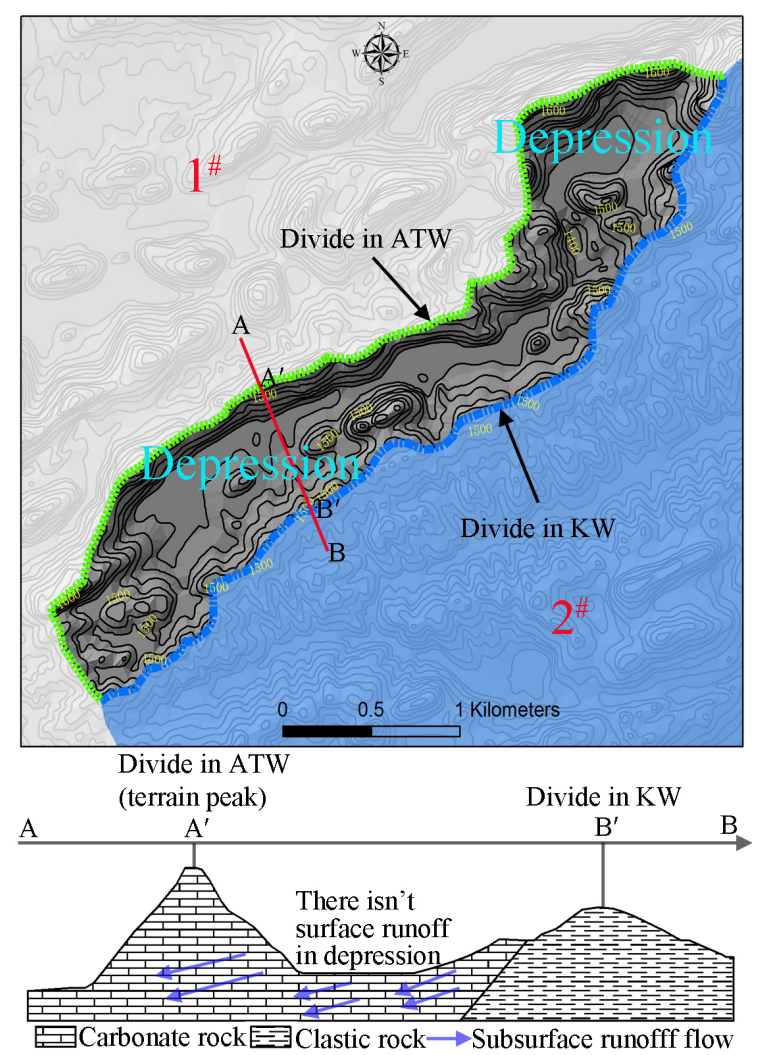

Figure 4. Correction divide based on the auto-delineating topographic watersheds (ATW) boundary in the depression area. KW represents "karst watersheds".

of ATW; i.e. correction on the automatically extracted divide is not needed. (2) In carbonatite areas characterized by underground corrosion where vertical permeation and subsurface runoff are the dominant hydrological processes (negative relief develops well in these areas and peak cluster depression is the main topographic feature), correction of ATW boundary and watershed distribution is completed by using hydrogeological data and high-resolution images and by using the flow direction determined in Sect. 3.4. In this regard, an example is shown in Fig. 4. A depression with no surface runoff is observed in the dividing area between $\mathrm{KW} 1$ and $\mathrm{KW} \mathrm{2,} \mathrm{and} \mathrm{the} \mathrm{hydrological} \mathrm{process} \mathrm{is} \mathrm{absolutely} \mathrm{differ-}$ ent from that of surface terrain. Underground runoffs in the depression flows through $A^{\prime}$ (terrain peak) and sunken pipes in karst carbonatite areas and accumulates in KW 1. However, the true divide goes through the water-resisting layer of clastic rocks where $B^{\prime}$ is located. Accordingly, we conducted manual correction on the watershed divide on the basis of the features of the underground hydrological process. 


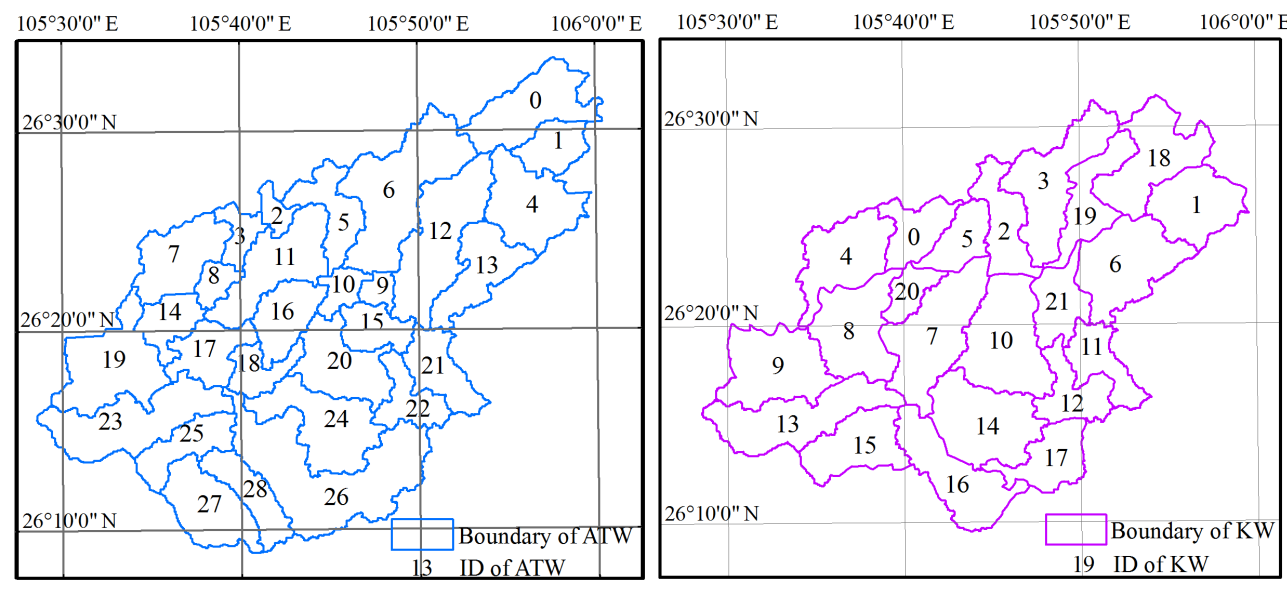

Figure 5. A quantitative contrast between karst watersheds (KW) and auto-delineating topographic watersheds (ATW).

\section{Results}

\subsection{Comparison of the topographic characteristics of auto-delineating topographic watersheds (ATW) and karst watersheds (KW)}

From the perspective of quantity, 22 small KWs are extracted in the study area. Compared with those based on DEMs, the number of watersheds was reduced by seven (Fig. 5), a decrease of $24 \%$. For the watershed boundary, the total length of the boundaries of small watersheds on the surface obtained based on the DEMs in the study area is $1381.47 \mathrm{~km}$. The total length of the boundaries of KWs is $1004.18 \mathrm{~km}$. The length of the boundaries shared by these two types is $394.36 \mathrm{~km}$, accounting for $28.5 \%$ of surface watershed boundaries and $39.27 \%$ of KW boundaries.

In terms of the superimposition of watersheds, the number of watersheds that reached the level of coupling is nine in ATW and KW. The number of watersheds without any coupling is also nine, and the number of approximate coupling is four (Table 3). Furthermore, except for watershed 3\#, at least two pairs of superimposition of surface watersheds are observed in all the other small KWs.

\subsection{Comparison of the features of the hydrological process between auto-delineating topographic watersheds (ATW) and karst watersheds (KW)}

The linear correlation between the water flow of subsurface runoff (or karst spring) in normal seasons (from May to October), which is 1 of the 13 rivers with water flow obtained previously, and the area of the upstream catchment is examined. In KW, the linear correlation coefficient $\left(R^{2}\right)$ between the water flow in normal seasons and the area of the upstream catchment is 0.84 (Fig. 6). In addition, Table 4 shows the proportions of atmospheric precipitation in the upstream catchment area of 13 subterraneous rivers (or karst springs) that are converted into subsurface runoffs. The values of $2,3,4$,

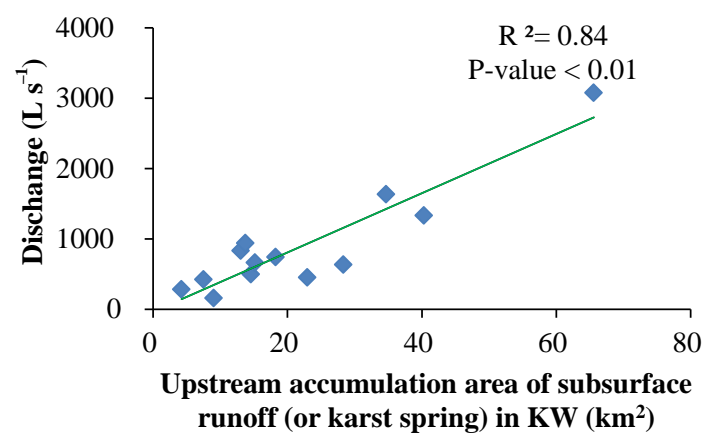

Figure 6. Correlation between the discharge of subsurface runoffs (or karst springs) and the upstream watershed area in karst watersheds $(\mathrm{KW})$.

$5,6,7,8,9,10,11$, and total $R_{\text {ATW }}$ are all greater than 100 , thus indicating that the upstream catchment areas extracted automatically are small. Accordingly, the $R_{\mathrm{KW}}$ values of 13 subsurface runoffs (or karst springs) are all less than 100 , thus indicating that the small KW that we extracted is reasonable.

\section{Discussion}

\subsection{The novel approach of delineation karst watersheds $(\mathrm{KW})$}

The automatic delineation of watersheds is extensively accepted and applied by hydrologists, geologists, and ecologists internationally because of the convenience in the acquisition of data source and automation in the extraction process (Verdin and Verdin, 1999). However, in karst areas, wherein the eco-hydrogeological principles are complex and significant differences exist in the dual structure of the surface and underground (Yang, 1982). This study has presented a novel approach to overcome faults of the traditional method 
Table 3. Evaluation of the spatio-superimposed relationship between karst watersheds $(\mathrm{KW})$ and auto-delineating topographic watersheds (ATW).

\begin{tabular}{lrlrrl}
\hline $\begin{array}{l}\text { ID of } \\
\text { KW }\end{array}$ & $\begin{array}{r}\text { Area } \\
\left(\mathrm{km}^{2}\right)\end{array}$ & ID of ATW Fig. 6 & $\begin{array}{r}\text { Maximum } \\
\text { of ATW }\end{array}$ & Percentage & Type \\
\hline & 29.91 & $2,3,11,8$ & 15.31 & 51.19 & No coupling \\
1 & 48.35 & 1,4 & 47.03 & 97.28 & Coupling \\
2 & 37.14 & $5,6,10,11,9$ & 27.93 & 75.20 & Segmental coupling \\
3 & 65.46 & 6 & 65.46 & 100.00 & Coupling \\
4 & 52.80 & $7,8,14$ & 45.92 & 86.95 & Segmental coupling \\
5 & 26.86 & 11 & 26.86 & 100.00 & Coupling \\
6 & 65.57 & $4,12,13$ & 42.99 & 65.56 & No coupling \\
7 & 72.98 & $5,10,16,17,18,24,26,11$ & 33.41 & 45.78 & No coupling \\
8 & 59.29 & $7,8,14,17,19,23,11$ & 25.11 & 42.35 & No coupling \\
9 & 62.32 & 19,23 & 56.83 & 91.20 & Coupling \\
10 & 71.73 & $9,10,16,20,24,15$ & 46.97 & 65.48 & No coupling \\
11 & 30.35 & 21,22 & 30.28 & 99.76 & Coupling \\
12 & 31.45 & $15,20,22,26,21$ & 26.22 & 83.40 & Segmental coupling \\
13 & 66.39 & 23,26 & 65.51 & 98.67 & Coupling \\
14 & 67.80 & $20,24,26$ & 55.12 & 81.31 & Segmental coupling \\
15 & 44.71 & $23,25,28,27$ & 31.09 & 69.53 & No coupling \\
16 & 57.16 & $25,26,28$ & 55.86 & 97.71 & Coupling \\
17 & 34.92 & $22,24,26$ & 33.96 & 97.24 & Coupling \\
18 & 59.23 & $0,1,12,13,4$ & 23.75 & 40.10 & No coupling \\
19 & 37.96 & $6,9,12$ & 21.70 & 57.17 & No coupling \\
20 & 17.07 & $3,8,11$ & 16.60 & 97.27 & Coupling \\
21 & 32.28 & $9,12,20,15$ & 14.45 & 44.77 & No coupling \\
\hline
\end{tabular}

Notes: no coupling-percentage $<70$; segmental coupling $70 \leq$ percentage $<90$; coupling $90 \leq$ percentage.

of delineation watersheds in karst areas, by combining hydrogeological principles and DEMs. The method proposed in this study not only had similar advantages of accurate expression of terrain and quick automation as the traditional automatic extraction method but also considered the specific eco-hydrogeological principles in karst areas.

The multiple methods from the geography, topography, hydrology, and hydrogeology were used conformably in the five steps of delineation KW. The work extends previous studies on watershed delineation using $3 \mathrm{~S}$ (GIS, RS, and GPS) and digital terrain data (Hollenhorst et al., 2007; Seyler et al., 2009). In these studies, watershed delineation has the following advantages: (i) the DEMs data (e.g. the Shuttle Radar Topography Mission DEMs and the Advanced Spaceborne Thermal Emission and Reflection Radiometer - global digital elevation model) is easy available (Jarihani et al., 2015); and (ii) Surface morphology analysis based on DEMs is accurate in the digital mapping to ditch, slope, mountain divide, and drainage network, with the advantages of high automation and wide spatial scale from the global to the nano - or microscales (Wilson and Gallant, 2000).

On the other hand, in the research fields of karst hydrology and karst hydrogeology, the study of watershed delineation most concentrated on delineation the catchment area of a single spring (Table 1) (e.g. Fontaine de Vaucluse Spring in the southeastern karst region of France; St. Ivan karst spring in the centre of the Istria peninsula of Croatia; Ombla karst spring in Croatia) or a ground runoff (e.g. Cuatrociénegas of Mexico) using geophysical and geochemical methods (Bonacci, 2001; Wolaver et al., 2008). In these cases it is reliable that determined the catchment area of the ground runoff on the surface, but expensive and impracticable that the methods are applied to a greater geographical spatial scales. Therefore, this study has combined the above two advantages to delineate $\mathrm{KW}$ based on the dual structure of the surface and subsurface, and this integrative delineation $\mathrm{KW}$ framework can be applied to map karstic catchments in multi-scales.

\subsection{The minimum karstic watershed unit}

In the field of topography, the key of watershed delineation is the extraction of drainage network that can be divided into different rank, accordingly, the rank of the watershed can be divided respectively (Fürst and Hörhan, 2009). Moreover, one of the most critical issues in deriving drainage networks from DEMs is the location of the channel head in the ArcHydrology tool (Vogt et al., 2003). Therefore, whatever a contributing area threshold to generate headwater can be defined and then the vary drainage network and watershed can be delineated. 
Table 4. Infiltration efficiency from the atmospheric precipitation in the upstream catchment area of subsurface runoffs (or karst springs). No. is the number of subsurface runoff or karst spring, and $D$ is its discharge $\left(\mathrm{L} \mathrm{s}^{-1}\right) . A_{\mathrm{kw}}$ represents "upstream accumulation area of subsurface runoff (or karst spring) in karst watersheds $\left(\mathrm{KW}, \mathrm{km}^{2}\right)$ " and $A_{\mathrm{ATW}}$ represents "upstream accumulation area of subsurface runoff (or karst spring) in auto-delineating topographic watersheds (ATW, $\mathrm{km}^{2}$ )". $R_{\mathrm{ATW}}(\%)$ is the percentage of precipitation into subsurface runoff in ATW and $R_{\mathrm{KW}}(\%)$ is the percentage of precipitation into subsurface runoff in $\mathrm{KW}$.

\begin{tabular}{lrrrrr}
\hline No. & $D$ & $A_{\mathrm{KW}}$ & $A_{\mathrm{ATW}}$ & $R_{\text {ATW }}$ & $R_{\mathrm{KW}}$ \\
\hline 1 & 3076.00 & 65.57 & 69.92 & 58.42 & 62.29 \\
2 & 1634.20 & 34.69 & 4.01 & 540.96 & 62.56 \\
3 & 1331.10 & 40.31 & 4.61 & 383.29 & 43.85 \\
4 & 940.20 & 13.72 & 0.07 & 16970.80 & 90.97 \\
5 & 832.51 & 13.05 & 1.16 & 956.17 & 84.72 \\
6 & 740.00 & 18.22 & 1.93 & 508.47 & 53.94 \\
7 & 660.60 & 15.14 & 6.76 & 129.73 & 57.92 \\
8 & 632.49 & 28.30 & 1.27 & 663.94 & 29.68 \\
9 & 496.40 & 14.57 & 4.95 & 133.25 & 45.24 \\
10 & 450.00 & 22.94 & 2.31 & 258.45 & 26.05 \\
11 & 424.00 & 7.48 & 0.89 & 634.45 & 75.30 \\
12 & 279.80 & 4.21 & 3.93 & 94.51 & 88.18 \\
13 & 157.50 & 9.01 & 12.19 & 17.16 & 23.22 \\
Sum & 11654.80 & 287.22 & 113.99 & 135.77 & 53.88 \\
\hline
\end{tabular}

Notes: $R_{\mathrm{KM}}=\frac{\frac{D}{A_{\mathrm{KM}}} \times T \times r}{P} \times 100$ and $R_{\mathrm{ATM}}=\frac{\frac{D}{A_{\mathrm{ATM}}} \times T \times r}{P} \times 100$, where $T$ is the total number of seconds from May to October; $r$ is the factor for unit conversion in $D, A, T$, and $P ; p$ is $1197.2 \mathrm{~mm}$, which is the hourly rainfall amount recorded by the automatic weather station in CERN (Puding) from May to October in the study area.

However, Karst landscapes are influenced by three main factors: the geological setting, the influence of events within the Quaternary (the last ca. 1.8 million years), and recent processes (usually taken to cover events within the Holocene or the last ca. 10000 years) (Viles, 2003). In some areas, with the affection from the lithology and geological tectonic movement, and the domination from the Earth's crust uplift and the long-term corrosion (as described the above Sect. 3.2), runoffs often enter into ground conduits (Pitty, 1968). Then the inconsistency can be developed between the delineation watershed area by only considering the surface topography and the physical hydrological process (Fig. 3). Obviously, the watershed should not be further divided in such karst areas. This study has proposed that the minimum unit of the river basin in karst regions should be the watershed whose exit is the corrosion and corrasion baselevel, which ensures the coincident hydrological process of the dual structure of surface and subsurface.

\subsection{The method's applicability}

The method of delineation KW in this study has proposed karst based on the dual structure of surface and subsurface and should be used in the karst areas where a wide range of closed surface depressions, a well-developed underground drainage system, and a strong interaction between circulation of surface water and groundwater is typical (Bonacci, 2009). In contrast, (i) for the karst area covered by glaciers (e.g. northern Tibet, high alpine, cordillera), the karst solution processes are unlikely to be an important factor in karst landform development because of low solubilities and/ or low secondary porosity (Zhang, 1996; Plan et al., 2009; Viles, 2003); (ii) for steep slope in karst areas (e.g. the eastern Tibet plateau), the karst hydrological processes are dominated by surface runoff and the development degree of underground karst processes is low. In the above two areas, a watershed can be delineated by traditional method on the basis of the surface topography.

Moreover, the small watershed extracted by using the new method has a better application value in the management of regional water resources, ecological construction, and management of land utilization. On that account, this method can be utilized by fellow scientists and government managers from around the world. Furthermore, on the basis of the method proposed in this study, our subsequent study will be focused on further promotion of the level of automation in $\mathrm{KW}$ extraction.

\section{Conclusions}

In this study, we propose that, under specific ecohydrogeological backgrounds, the traditional method of automatic extraction of watershed based merely on surface topography is inauthentic and cannot reflect the ecohydrological process of the dual structure of the surface and subsurface accurately. Thus, a new method that is applicable for the extraction of small watersheds in karst areas is imperative. This study focuses on the eco-hydrological background of karst regions and proposes a new method for the extraction of small watershed in karst areas. The extraction of small watersheds is achieved through the following five steps: (i) automatic extraction of small watershed in the surface terrain is conducted (ATW); (ii) regional corrosion and corrasion baselevel and exit of watershed are determined; (iii) trunk stream of the dual structure of the surface and underground in karst regions is determined; (iv) flow direction in the permeable stratum of karst carbonatite in the regions where trunk stream flows through is determined; (v) divide of ATW is corrected. In this method, vector topographic data, geological data, hydrogeological data, and data source of high-resolution remote sensing are employed. By the combined utilization of ArcGIS platform and field survey, the extraction of small KWs is completed.

This method is applied to one section of the tributary area (Sancha River) of the Yangtze River in China. By comparing the quantity, shape, and superimposition between the traditional method of automatic extraction and the method proposed in this study, we can conclude that a significant incon- 
sistency exists between small watersheds extracted in karst areas by using the two methods. Furthermore, the hydrological processes in small watersheds extracted by using these two methods are compared. A significant amount of errors exist in the small watershed extracted automatically. By contrast, small KWs extracted by using the new method proposed in this study can reflect the hydrological process of watersheds accurately. On the basis of the results previously presented, we deem that the minimum unit of watershed in karst areas is the watershed whose exit is the corrosion and corrasion baselevel proposed in this study. A further subdivision of watershed may cause a significant inconsistency with the true eco-hydrological process.

Acknowledgements. This work was supported by the Chinese academy of sciences strategic leading science and technology projects (XDA05070401), the 973 Program of China (2013CB956704), the National Natural Science Foundation of China (41461041, 41473055) and the National Key Technology R\&D Program (2014BAB03B02).

Edited by: A. Jordán

\section{References}

Ahamed, T. R. N., Rao, K. G., and Murthy, J. S. R.: Automatic extraction of tank outlets in a sub-watershed using digital elevation models, Agricul. Water Man., 57, 1-10, 2002.

Bai, X. Y., Wang, S. J., and Xiong, K. N.: Assessing spatialtemporal evolution processes of karst rocky desertification land: indications for restoration strategies, Land Degrad. Develop., 24, 47-56, 2013.

Bailly-Comte, V., Jourde, H., and Pistre, S.: Conceptualization and classification of groundwater-surface water hydrodynamic interactions in karst watersheds: Case of the karst watershed of the Coulazou River (Southern France), J. Hydrol., 376, 456-462, 2009.

Band, L. E.: Topographic partition of watersheds with digital elevation models, Water Resour. Res., 22, 15-24, 1986.

Benosky, C. P. and Merry, C. J.: Automatic extraction of watershed characteristics using spatial analysis techniques with application to groundwater mapping, J. Hydrol., 173, 145-163, 1995.

Bonacci, O.: Analysis of the maximum discharge of karst springs, Hydrogeol. J., 9, 328-338, 2001.

Bonacci, O., Pipan, T., and Culver, D. C.: A framework for karst ecohydrology, Environ. Geol., 56, 891-900, 2009.

Doglioni, A., Simeone, V., and Giustolisi, O.: The activation of ephemeral streams in karst catchments of semi-arid regions, Catena, 99, 54-65, 2012.

Febles, J. M., Vega, M. B., Amaral, N. M. B., Tolón, A., and Lastra X. B.: Soil loss from erosion in the next 50 years in karst regions of Mayabeque province, Cuba, Land Degrad. Develop., 25, 573580, 2012.

Fitzpatrick, F. A.: Geomorphic and hydrologic responses to vegetation, climate, and base level changes, North Fish Creek, Wisconsin, University of Wisconsin-Madison, 1998.
Ford, D. and Williams, P.: Karst hydrogeology and geomorphology, John Wiley \& Sons Ltd., England, 2007.

Fürst, J. and Hörhan, T.: Coding of watershed and river hierarchy to support GIS-based hydrological analyses at different scales, Comput. Geosci., 35, 688-696, 2009.

Gallant, J. C. and Hutchinson, M. F.: A Differential Equation for Specific Catchment Area, Proceedings of Geomorphometry, Water Resour. Res., 47, 143-158, 2009.

García, M. J. L. and Camarasa, A. M.: Use of geomorphological units to improve drainage network extraction from a dem: comparison between automated extraction and photointerpretation methods in the carraixet catchment (valencia, spain), Int. J. Appl. Earth Obs., 1, 187-195, 1999.

Hancock, G. R., Martinez, C., Evans, K. G., and Moliere, D. R.: A comparison of SRTM and high-resolution digital elevation models and their use in catchment geomorphology and hydrology: Australian examples, Earth Surf. Proc. Land., 31, 1394-1412, 2006.

Hollenhorst, T. P., Brown, T. N., Johnson, L. B., Ciborowski, J. J. H., and Host, G. E.: Methods for generating multi-scale watershed delineations for indicator development in great lake coastal ecosystems, J. Great Lakes Res., 33, 13-26, 2007.

Jarihani, A. A., Callow, J. N., McVicar, T. R., Van Niel, T. G., and Larsen, J. R.: Satellite-derived Digital Elevation Model (DEM) selection, preparation and correction for hydrodynamic modelling in large, low-gradient and data-sparse catchments, J. Hydrol., 524, 489-506, 2015.

Jensen, S. K.: Application of hydrology information automatically extracted from digital elevation model, Hydrol. Process., 5, 3144, 1991.

Jenson, S. K. and Domingue, J. O.: Extracting topographic structure from digital elevation data for geographic information system analysis, Photogramm. Eng. Rem. S., 54, 1593-1600, 1988.

Jiang, Z. C., Lian, Y. Q., and Qin, X. Q.: Rocky desertification in Southwest China: impacts, causes, and restoration, Earth-Sci. Rev., 132, 1-12, 2014a.

Jiang, Z. C., Luo, W. Q., Deng, Y., Cao, J. H., Qin, X. M., Li, Y. Q., and Yang, Q. Y.: The leakage of water and soil in the karst peak cluster depression and its prevention and treatment, Acta Geosci. Sin., 35, 535-542 (in Chinese with English abstract), 2014b.

Khan, A., Richards, K. S., Parker, G. T., Mcrobie, A., and Mukhopadhyay, B.: How large is the upper indus basin? The pitfalls of auto-delineation using dems, J. Hydrol., 509, 442-453, 2014.

Kiss, R.: Determination of drainage network in digital elevation models, utilities and limitations, Hung. Geomath., 2, 16-29, 2004.

Li, C. F., Feng, X. Z., and Zhao, R.: The methods and application of automatically extracting stream network of watershed, J. Lake Sci., 15, 205-202 (in Chinese with English abstract), 2003.

Li, D. W. and Cui, Z. J.: Karst planation surface and the qinghaixizang plateau uplift, Quaternary Sci., 24, 58-66 (in Chinese with English abstract), 2004.

Li, L. and Hao, Z. C.: The automated extraction of catchment properties from digital elevation models, Adv. Earth Sci., 18, 251-256 (in Chinese with English abstract), 2003.

Liu, Y. H. and Li, X. B.: Fragile eco-environment and sustainable development, The Commercial Press, Beijing, Chapter 5, 246264, 2007. 
Majone, B., Bellin, A., and Borsato, A.: Runoff generation in karst catchments: multifractal analysis, J. Hydrol., 294, 176-195, 2004.

Malard, A., Jeannin, P., Vouillamoz, J., and Weber, E.: An integrated approach for catchment delineation and conduit-network modeling in karst aquifers: application to a site in the Swiss tabular Jura, Hydrogeol. J., 23, 1-7, doi:10.1007/s 10040-015-1287-5, 2015.

Mantelli, L. R., Barbosa, J. M., and Bitencourt, M. D.: Assessing ecological risk through automated drainage extraction and watershed delineation, Ecol. Inform., 6, 325-331, 2011.

Marks, D., Dozier, J., and Frew, J.: Automated basin delineation from digital elevation data, Geo-Processing, 2, 299-311, 1984.

Martz, L. W. and Garbrecht, J.: An outlet breaching algorithm for the treatment of closed depressions in a raster DEM, Comput. Geosci., 25, 835-844, 1999.

Mayaud, C., Wagner, T., Benischke, R., and Birk, S.: Single event time series analysis in a binary karst catchment evaluated using a groundwater model (Lurbach system, Austria), J. Hydrol., 511, 628-639, 2014.

McCormack, T., Gill, L. W., Naughton, O., and Johnston, P. M.: Quantification of submarine/intertidal groundwater discharge and nutrient loading from a lowland karst catchment, J. Hydrol., 519, 2318-2330, 2014.

Meng, H. H. and Wang, L. C.: Advance in karst hydrological model, Prog. Geogr., 29, 1311-1318 (in Chinese with English abstract), 2010.

Meng, X., Yin, M,, Ning, L., Liu, D., and Xu, X.: A threshold artificial neural network model for improving runoff prediction in a karst watershed, Environ. Earth Sci., 74, 5039-5048, 2015.

Navas, A., López-Vicente, M., Gaspar, L., and Machín, J.: Assessing soil redistribution in a complex karst catchment using fallout ${ }^{137}$ Cs and GIS, Geomorphology, 196, 231-241, 2013.

Nico, G. and David, D.: Methods in karst hydrogeology, Taylor \& Francis Group, London, 2007.

Nikolakopoulos, K. G., Kamaratakis, E. K., and Chrysoulakis, N.: SRTM vs ASTER elevation products. Comparison for two regions in Crete, Greece, Remote Sens., 27, 4819-4838, 2006.

NRC (National Research Council): New strategies for America's watersheds, National Academy Press, 1-4, 1999.

O'Callaghan, J. F. and Mark, D. M.: The extraction of drainage networks from digital elevation data, Comput. Vision Graph., 28, 323-344, 1984

Peng, T. and Wang, S. J.: Effects of land use, land cover and rainfall regimes on the surface runoff and soil loss on karst slopes in southwest china, Catena, 90, 53-62, 2012.

Peucker, T. K. and Douglas, D. H.: Detection of surface-specific points by local parallel processing of discrete terrain elevation data, Comput. Vision Graph., 4, 375-387, 1975.

Pitty, A. F.: Calcium carbonate content of karst water in relation to flow-through time, Nature, 5132, 939-940, 1968.

Plan, L., Decker, K., Faber, R., Wagreich, M., and Grasemann, B.: Karst morphology and groundwater vulnerability of high alpine karst plateaus, Environ. Geol., 58, 285-297, 2009.

Qiu, L. J. and Zheng, F. L.: Effects of dem resolution and watershed subdivision on hydrological simulation in the xingzihe watershed, Acta Ecol. Sin., 32, 3754-3763, 2012.

Qiu, L. J., Zheng, F. L., and Yin, R. S.: Effects of DEM resolution and watershed subdivision on hydrological simulation in the
Xingzihe watershed, Acta Ecol. Sin., 32, 3754-3763 (in Chinese with English abstract), 2012.

Ravbar, N. and Goldscheider, N.: Comparative application of four methods of groundwater vulnerability mapping in a Slovene karst catchment, Hydrogeol. J., 17, 725-733, 2009.

Rimmer, A. and Salingar, Y.: Modelling precipitation-streamflow processes in karst basin: The case of the Jordan River sources, Israel, J. Hydrol., 331, 524-542, 2006.

Rugel, K., Golladay, S. W., Rhett, J. C., and Rasmussen, T. C.: Delineating groundwater/surface water interaction in a karst watershed: Lower Flint River Basin, southwestern Georgia, USA, J. Hydrol., 5, 1-19, 2016.

Seyler, F., Muller F., Cochonneau, G., Guimarães, L., and Guyot, J. L.: Watershed delineation for the Amazon sub-basin system using GTOPO30 DEM and a drainage network extracted from JERS SAR images, Hydrol. Process., 23, 3173-3185, 2009.

Soille, P. J. and Ansoult, M. M.: Automated basin delineation from digital elevation models using mathematical morphology, Signal Process., 20, 171-182, 1990.

Tarboton, D. G., Bras, R. L., and Rodriguez-Iturbe, I.: On the extraction of channel networks from digital elevation data, Hydrol. Process., 5, 81-100, 1991.

Verdin, K. L. and Verdin, J. P.: A topological system for delineation and codification of the Earth's river basins, J. Hydrol., 218, 1-12, 1999.

Viles, H. A.: Conceptual modeling of the impacts of climate change on karst geomorphology in the UK and Ireland, J. Nat. Conserv., 11, 59-66, 2003.

Vogt, J. V., Colombo, R., and Bertolo, F.: Deriving drainage networks and catchment boundaries: a new methodology combining digital elevation data and environmental characteristics, Geomorphology, 53, 281-298, 2003.

Wang, S. J., Li, Y. B., and Li, R. L.: Karst rocky desertification: formation background, evolution and comprehensive taming, Quaternary Sci., 23, 657-666 (in Chinese with English abstract), 2004.

Wicks, C. M.: Origins of groundwater in a Fluviokarst basin: Bonne Femme basin in central Missouri, USA, Hydrogeol. J., 5, 89-96, 1997.

Wilson, J. P. and Gallant, J. C.:Terrain analysis principles and applications, John Wiley \& Sons, Canada, Chapter 1, 1-30, 2000.

Wolaver, B. D., Sharp Jr., J. M, Rodriguez, J. M., and Ibarra Flores, J. C.: Delineation of Regional Arid Karstic Aquifers: An Integrative Data Approach, Ground Water, 46, 396-413, 2008.

Xiao, H., Xiong, K. N., Zhang, H., and Zhang, Q. Z.: Research progress for karst rocky desertification control models, China Population, Resour. Environ., 25, 330-334 (in Chinese with English abstract), 2014.

Xiong, K. N., Li, J., and Long, M. Z.: Features of soil and water loss and key issues in demonstration areas for combating karst rocky desertification, Acta Geogr. Sin., 67, 877-888 (in Chinese with English abstract), 2014.

Xu, E. Q., Zhang H. Q., and Li, M. X.: Object-based mapping of karst rocky desertification using a support vector machine, Land Degrad. Develop., 26, 158-167, 2015.

Yan, D. X.: Rock desertification in the subtropical karst of South China, Z. Geomorphol., 108, 81-90, 1997. 
Yan, X. and Cai, Y. L.: Multi-scale anthropogenic driving forces of karst rocky desertification in southwest china, Land Degrad. Develop., 26, 193-200, 2015.

Yang, M. D.: The geomorphological regularities of karst water occurences in guizhou plateau, Carsologica Sin., 2, 81-91 (in Chinese with English abstract), 1982.

Yue, F. J., Li, S. L., Liu, C. Q., Lang, Y. C., and Ding, H.: Sources and transport of nitrate constrained by the isotopic technique in a karst catchment: an example from Southwest China, Hydrol. Process., 29, 1883-1893, 2015.
Zhang, D.: A morphological analysis of Tibetan limestone pinnacles: Are they remnants of tropical karst towers and cones?, Geomorphology, 15, 79-91, 1996.

Zhang, J. F., Feng, X. B., Yan, H. Y., Guo, Y. N., Meng, B., and Yao, H.: Spatial and temporal distribution of mercury species in water in yelanghu reservoir, Chinese J. Ecol., 30, 969-975 (in Chinese with English abstract), 2011. 